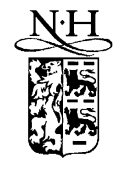

\title{
Bankruptcy auctions: costs, debt recovery, and firm survival ${ }^{\text {is }}$
}

\author{
Karin S. Thorburn \\ Amos Tuck School of Business Administration, Dartmouth College, Hanover, NH 03755, USA
}

\begin{abstract}
This paper provides some first, large-sample evidence on the Swedish auction bankruptcy system. Compared to U.S. Chapter 11 cases, the small-firm bankruptcy auctions examined here are substantially quicker, have lower costs, and avoid deviations from absolute priority. Three-quarters of the firms are auctioned as going concerns, which is similar to Chapter 11 survival rates. Moreover, based on market values, creditors in going-concern auctions recover a similar fraction of face value as creditors of much larger firms in Chapter 11 reorganizations. The evidence presented here suggests that the auction bankruptcy system is a surprisingly efficient restructuring mechanism for small firms. (C) 2000 Elsevier Science S.A. All rights reserved.
\end{abstract}

JEL classification: G33; G34; K22

Keywords: Auctions; Bankruptcy costs; Debt recovery; Prepacks; Chapter 11

\footnotetext{
This work is derived from my doctoral dissertation at the Stockholm School of Economics. I wish to thank, in particular, B. Espen Eckbo for valuable comments. I am also grateful for the comments by Peter Björnram, Ted Eisenberg, Julian Franks (the referee), Ron Giammarino, Jonathan Karpoff, Kai Li, Wayne Mikkelson, Todd Pulvino, Stefan Sundgren, Liz Tashjian, Larry Weiss, the finance seminar participants at Dartmouth College, Duke University, Harvard Business School, the Norwegian School of Economics, the Norwegian School of Management, Penn State University, the Stockholm School of Economics, the universities of Illinois, Toronto, and Vienna, the meetings of the 1997 European Finance, the 1998 Western Finance, and the 1999 American Law and Economics associations, and the 1998 Utah Winter Finance Conference. This research has received financial support from Bankforskningsinstitutet, NÖDFOR, Sparbankernas Forskningsstiftelse, and the Norwegian Research Council (Norges Forskningsråd), Grant no. 125105/510.
}

E-mail address: karin.s.thorburn@dartmouth.edu (K.S. Thorburn). 


\section{Introduction}

Different bankruptcy procedures allocate different sets of control rights to incumbent managers and the security holders of a firm, thus affecting both the timing and form of management's choice of bankruptcy venue. For example, Chapter 11 of the U.S. bankruptcy code allows managers to retain a certain degree of control over the firm's assets and operations while in bankruptcy. Managers are thus encouraged to select a court-supervised debt renegotiation under Chapter 11 rather than file for liquidation in Chapter 7. In contrast, the Swedish bankruptcy code, which constitutes the empirical laboratory of this study, has no effective reorganization provisions and all bankruptcy filings are resolved through a public auction requiring payment in cash. In this auction, the firm is either liquidated piecemeal or survives as a going concern. The auction is run by an independent, court-appointed trustee, and incumbent management and shareholders immediately lose their control rights.

The relative efficiency of court-supervised reorganizations and bankruptcy auctions is a largely unexplored empirical issue, and systematic evidence on the outcomes of auction bankruptcy is sparse. ${ }^{1}$ In this study, I present evidence on 263 small-firm bankruptcy auctions in Sweden and perform a systematic comparison with extant evidence on Chapter 11 cases. $^{2}$ To enhance comparability with the U.S. evidence, which is generally based on large firms, the analysis includes control variables reflecting firm size, financing structure, and ownership structure. The paper further adds to the bankruptcy literature by including controls for industry distress, asset uniqueness, and operating profitability relative to the filing firm's competitors. Furthermore, the paper is the first to examine prepackaged bankruptcy filings under an auction system, which I refer to as auction prepacks.

There is an ongoing debate as to the merits of an auction bankruptcy system. Proponents point to the benefits of market valuation over court-administered value assessment. ${ }^{3}$ Sale to the highest-valuation bidder also reduces the scope for agency conflicts and disagreement among existing claimholders, and thus lowers bankruptcy costs. Moreover, the requirement for cash payment allows settlement of debt claims strictly according to absolute priority rules (APR). On

\footnotetext{
${ }^{1}$ Exceptions are Ravid and Sundgren (1998), who examine 72 bankruptcy auctions in Finland, and Strömberg (2000).

${ }^{2}$ There is no comparable evidence on Chapter 7 cases. Also, although $99.5 \%$ of all Chapter 11 filings are by small, privately held firms of the type studied here (Altman, 1993), available studies of Chapter 11 bankruptcies focus on large, publicly traded companies. Note also that the prospect of empirical biases due to self-selection of firms filing for alternative bankruptcy chapters (such as Chapter 11 vs. Chapter 7) is not a concern in the Swedish, single-chapter environment.

${ }^{3}$ See, e.g., Roe (1983), Baird (1986), Bebchuk (1988), Jensen (1991), and Bradley and Rosenzweig (1992).
} 
the other hand, opponents of the auction system warn that it is likely to induce delayed filing and costly pre-filing asset substitution due to adverse managerial incentives and agency conflicts between holders of equity and holders of debt. Moreover, it has been argued that auctions involve a substantial risk of losses due to asset "fire-sales". 4

The empirical analysis below addresses this debate by focusing on three important characteristics of the outcomes of bankruptcy auctions. First, I provide evidence on firm survival rates to address the extent to which the auction system promotes continuation of the bankrupt firm as a going concern. Of the 263 cases, $75 \%$ survive as a going concern, either through pre-filing auction prepack $(20 \%)$ or through post-filing auction sale. In the remaining $25 \%$ of the cases, the firm's assets are liquidated piecemeal. The $75 \%$ survival rate is similar to the percentage of small firms that survive as a going concern through Chapter 11 proceedings, as reported by White (1984). I also find that, as expected, the probability of a firm being sold as a going concern increases with the proportion of intangible assets. Auction prepacks are more likely to occur the larger the firm and, interestingly, when the firm is run by an owner-manager. While shareholders themselves have few incentives to initiate a prepack, which eradicates their equity claims, owner-managers may use a prepack to maintain control benefits and to enhance their market value as managers with the new owners.

Second, I provide evidence on bankruptcy costs. Direct costs in percent of pre-filing book value of assets average $6.4 \%$ across the sample of firms undergoing auctions in bankruptcy, and $3.7 \%$ for the one-third largest firms. Auction prepacks are generally low-cost with an average direct cost of $2.5 \%$. Regressions indicate that direct costs have a significant fixed component, which probably accounts for the size effect, and are lower for piecemeal liquidations. Interestingly, direct costs are increasing in industry distress, where distress is measured as the proportion of firms sharing the same 4-digit Standard Industrial Classification (SIC) code that either have an interest coverage ratio of less than one or file for bankruptcy that year. One possible explanation for this result is that the trustee increases marketing efforts in response to lower auction demand induced by industry distress. The direct cost estimate for the largest firms in my sample corresponds closely to the typical cost of large-firm Chapter 11 cases reported by Weiss (1990) and Betker (1997). Averaging across the samples studied by Weiss (1990) and Betker (1997), the sample-size weighted mean of direct costs for publicly traded firms undergoing Chapter 11 reorganization is $3.6 \%$. Moreover, there is reason to believe that total costs, calculated as the sum of direct and indirect costs, are lower in Sweden. Indirect costs increase with the length of time spent in bankruptcy, and Swedish bankruptcy auctions are unquestionably

\footnotetext{
${ }^{4}$ For example, Shleifer and Vishny (1992), Aghion et al. (1994), Berkovitch and Israel (1995), White (1996), and Pulvino (1998). Eckbo and Thorburn (2000a) fail to find support for asset fire-sales in Swedish bankruptcy auctions.
} 
speedy. On average, two months pass from filing for bankruptcy to sale as a going concern. In contrast, it typically takes about two years to resolve small-firm reorganizations under Chapter 11 (see, e.g., Flynn, 1989).

Third, I report evidence on debt recovery rates. Importantly, the cash settlement from the auction directly yields the market value of the recovery. Overall, debtholders recover $35 \%$ of the face value of their claims, with a $27 \%$ mean recovery rate for piecemeal liquidations and 39\% recovery for going concern sales. In comparison, Franks and Torous (1994) provide market-value estimates for a subsample of 12 Chapter 11 cases which resulted in successful reorganizations, and find that the median overall recovery is $41 \%$, similar to that of firms auctioned as going concerns. Franks and Torous (1994) is, to my knowledge, the only study that reports recovery rates in Chapter 11 that are based entirely on market values. Given the default rates of firms emerging from Chapter 11 bankruptcy (Hotchkiss, 1995), debt face values tend to overstate market values of debt, and thus overstate recovery rates. I find that secured debtholders receive on average $69 \%$ of their claims, while junior unsecured creditors recover only $2 \%$ on average. The distribution of recovery rates is skewed, with a median of $82 \%$ for secured debt and $0 \%$ for unsecured creditors. As expected, recovery rates are lower the greater the fraction of intangible assets and in years with a general economic downturn. Interestingly, secured debtholders recover more when the original owner buys back the firm and when the old bank finances the buyer in the auction. While not pursued here, this evidence suggests that the decision to repurchase or refinance the bankrupt firm in part reflects private information about firm value.

This study concludes that the Swedish auction bankruptcy system promotes firm survival rates, bankruptcy costs, and debt recovery rates that compare favorably with the reorganization system in the U.S. Overall, the evidence presented here suggests that auctions constitute a surprisingly efficient mechanism for restructuring small firms in bankruptcy.

The rest of the paper is organized as follows. Highlights of the Swedish bankruptcy code, data sources and sampling procedures are contained in Section 2. Section 3 presents evidence on the use of auction prepacks, and firm survival in bankruptcy auctions. Section 4 examines direct bankruptcy costs, while debt recovery rates are discussed in Section 5. Section 6 concludes the paper.

\section{Legal rules summary and sample characteristics}

\subsection{Highlights of the Swedish auction bankruptcy code}

Table 1 summarizes central characteristics of the legal rules under Swedish auction bankruptcy and shows the comparable rules under Chapter 11 in the 


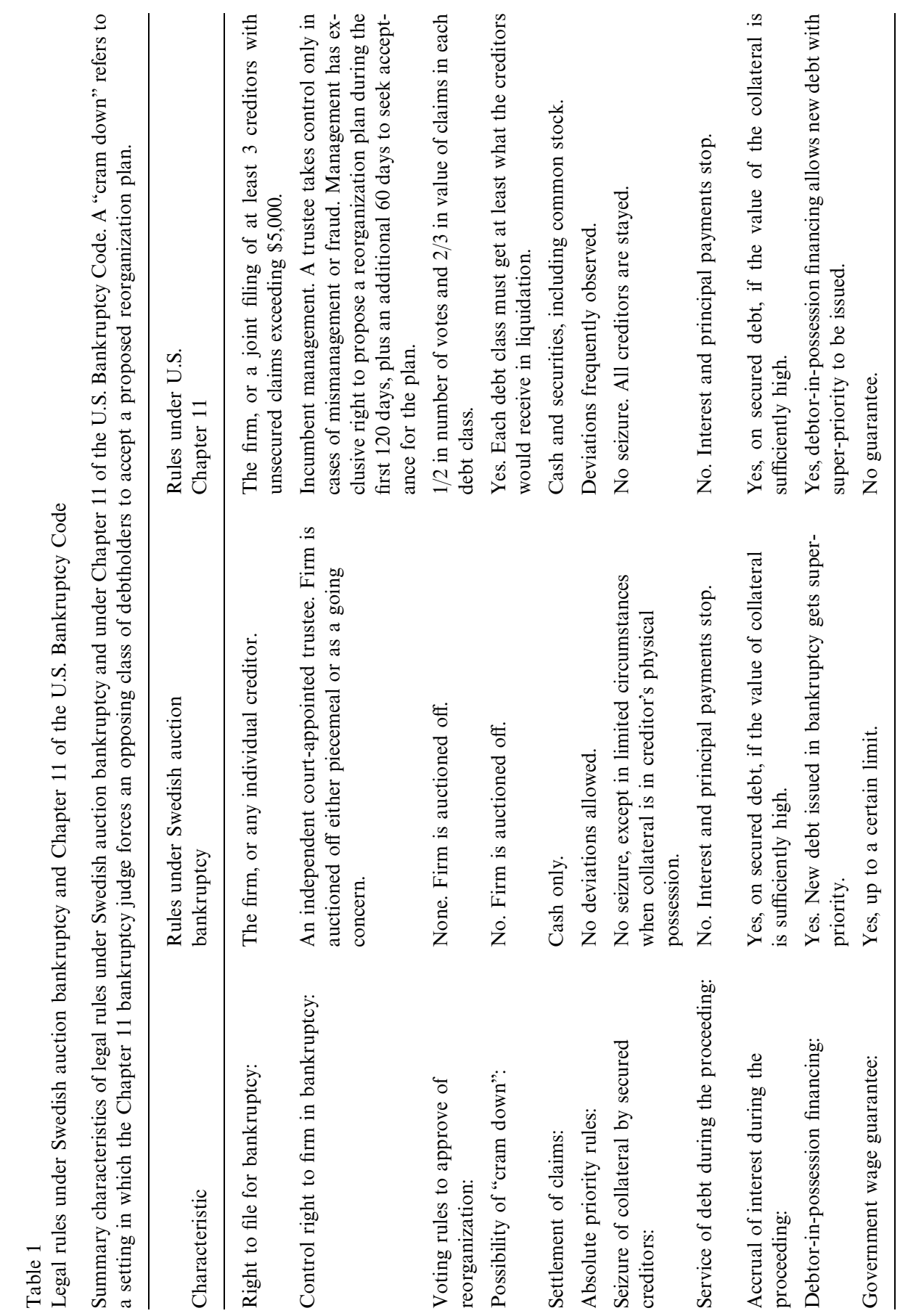


U.S. In Sweden, as an alternative to auction bankruptcy, an insolvent firm can file for composition, or "ackord", which is a court-supervised procedure for renegotiation of unsecured (junior) debt claims. The composition procedure, however, provides no protection for the firm against its secured debtholders and holders of priority claims, and is therefore almost never used. In preliminary work, Eckbo and Thorburn (2000b) find that in a sample of 1,650 financially distressed firms, only 4 firms file for composition over the next two years, while almost 300 firms file for bankruptcy.

In Swedish bankruptcy, the incumbent management team is immediately replaced by an independent, court-appointed trustee with a fiduciary responsibility towards creditors. The trustee organizes the sale of the firm's assets in an open ascending English-style auction, either piecemeal or as a going concern. A going concern sale takes place by merging the assets and operations of the firm into a receiving company which is either established or held by the buyer. The auction typically attracts 3-4 bidders, and payments are restricted to cash only. The bulk of cash represents bank debt financing provided to the buying corporation, much like in a leveraged buyout. As under Chapter 11, the operations of a firm in auction bankruptcy are protected through automatic stay of creditors. In other words, once the trustee takes over, debt service is halted and creditors cannot seize collateral. Furthermore, the code permits debtorin-possession financing such that the firm can issue new debt claims with superpriority status over all existing debt claims. In practice, bankrupt firms tend to cover operating expenses by increasing their debt obligations in the form of trade credits which get super-priority, while new debt issues or bank loans are almost never observed.

The bankruptcy auction is supervised by the provincial supervisory authority, known as "Tillsynsmyndigheten i Konkurs" (TSM). This supervision, the legal constraints on the trustee, and the value of the trustee's own reputation all increase the trustee's incentives to fulfill his or her responsibility to the filing firm's creditors. This setting contrasts with the U.S. reorganization code which provides a strong protection of managers and equityholders. During the Chapter 11 proceeding, incumbent managers usually remain in control of the firm. Management has an exclusive right to propose a reorganization plan during the first four months, and receive another two months to seek approval of the plan. Moreover, shareholders participate in the voting of the proposed plan and are often allowed to retain some equity.

The cash proceeds from the bankruptcy auction are distributed to creditors strictly according to APR. Payment of administrative and advisory costs of the bankruptcy proceeding has super-priority along with any new debtor-in-possession financing. Secured claims are entitled to the proceeds from sale of collateral, and any unpaid part of the claim is treated as an unsecured claim. The vast majority of firms have floating charge secured claims, pledging as collateral the movable property of the firm, such as machinery, inventory, and accounts 
receivables. Prior to filing, the floating charge asset base can shrink, or grow, at the discretion of the firm's manager, by selling or purchasing machinery, for example, or decreasing or increasing inventory. Moreover, individual assets, like a machine or inventory, contained in the floating charge asset base can be taken as collateral for a fixed charge claim. In contrast, fixed charge debt have a claim to a specific asset that cannot be sold without creditor approval. Floating charge claimholders thus have less control rights than fixed charge claimholders.

Debt claims are paid in the following order: super-priority claims, secured claims, both fixed and floating charge, certain audit claims, tax claims, wage claims, and, lastly, unsecured or junior claims. Audit, tax, and wage claims have statutory priority to the unsecured claims, and are classified as priority claims in this paper. Note that the Swedish government guarantees the payment of wage claims up to a certain limit, while there is no corresponding guarantee in the U.S. Since Swedish priority rules prescribe equal treatment of all unsecured claims, firms effectively cannot issue different classes of unsecured debt. I therefore use the term unsecured debt and junior debt interchangeably.

\subsection{Data sources}

I analyze a sample of Swedish bankruptcies compiled by Strömberg and Thorburn (1996) that are restricted to firms with at least 20 employees. This sample is identified from UpplysningsCentralen AB's database (UC), which contains a total of 1,159 bankruptcy filings from January 1, 1988 through December 31, 1991. The UC database, which is restricted to bankruptcy cases that remained open on December 31, 1991, covers virtually the entire population of filings over the sample period. The reason is that a bankruptcy case cannot be formally closed until all claims owned by the filing firm are fully collected, which can take several years. The data collection was restricted to the four largest administrative provinces in Sweden, which are Stockholms län, Göteborg- och Bohus län, Malmöhus län, and Upplands län. Of the total 1,159 filings, the sampling procedure eliminates the following cases: 581 firms located outside the selected geographical area, 145 cases which are pending in bankruptcy on June 30, 1995, 59 cases that are related to tax fraud charges, and 111 cases for which the bankruptcy file is either missing or incomplete. The final sample consists of 263 cases, of which 9 filed in 1988, 27 in 1989, 71 in 1990, and 156 in 1991.

For each firm in the sample, information on firm characteristics and casespecific characteristics is collected from the bankruptcy file kept by the provincial supervisory authority. Pre-bankruptcy financial statements are obtained from UC. Moreover, UC also provides annual financial statements from the period 1987-1994 for the Swedish population of more than 15,000 firms that had 
at least 20 employees and were in operation on December 31, 1991. This information is used below to construct industry distress and profitability measures.

The paper extends the original dataset and compiles information on the identity of the financing source of the buyer in the auction, typically a bank, as well as the stock ownership of the incumbent CEO. The former is from the national register of corporate floating charge claims (Inskrivningsmyndigheten för företagsinteckning), and allows classification of each case as to whether or not the filing firm's bank participates in the financing of the successful buyer in the auction. Of the 195 going concern sales, the role of the old bank is identified for 108 cases. CEO stock ownership is compiled by matching the information on management and owners in the bankruptcy file, with board information provided by UC. This matching process produces the stock ownership for 215 CEOs.

\subsection{Sample characteristics}

Of the 263 bankrupt firms, 63 (24\%) are liquidated piecemeal and 195 (74\%) are sold as a going concern. In the remaining 5 cases $(2 \%)$, there is insufficient information to classify the case as either a going concern sale or a piecemeal liquidation. In this classification, a going concern sale is a joint sale of the firm's core assets, defined as assets essential for the continued operations, such as inventories, machinery, vehicles, unfinished products, intangible assets, industrial estate, and rental contracts. The classification of each firm into piecemeal liquidation, going concern sale, and auction prepack has been confirmed by the respective trustee. Firms sold as going concerns are repurchased by the original owner in $54 \%$ of the cases.

The firms in the sample represent the larger firms in Sweden. Only 6\% of Swedish corporations have 20 employees or more, and $90 \%$ of firms have less than 10 employees (source, Statistics Sweden). If liquidation rates are higher for the very small firms, which constitute the bulk of businesses, the liquidation rate across all business bankruptcies in Sweden may be significantly higher than the $24 \%$ found here. In the U.S., for example, Altman (1993) reports that $60 \%$ of all business bankruptcies are Chapter 7 filings.

The sample firms represent more than 30 different 2-digit SIC groups. The largest number of cases, 76 firms, occur in the manufacturing industry. Of the remaining cases, 33 are in the construction industry, 30 firms are wholesale companies, 26 firms are hotels and restaurants, while 26 cases are from the transportation industry. All firms are privately held, and most have concentrated ownership. Of the 181 sample firms with information available regarding shareownership, $56 \%$ are wholly owned by one individual or family. For another $31 \%$, at least half of the equity is controlled by a single shareholder. Moreover, three-quarters of the firms are run by an 
Table 2

Pre-filing characteristics of Swedish and U.S. firms filing for bankruptcy or initiating a workout, 1978-1990

Table shows pre-filing financial characteristics of 263 privately held Swedish firms filing for auction bankruptcy in 1988-1991, and for publicly traded U.S. firms filing for Chapter 11 or initiating workouts during 1978-1990. For the sample of Swedish firms, the numbers shown are book values, denoted in 1991 prices, from the last financial statement reported prior to bankruptcy filing, dated on average 16.5 months before filing. Data for the Swedish firms are from the database of UpplysningsCentralen AB (UC). The information on publicly traded firms in Chapter 11 is from Weiss (1990), Gilson et al. (1990), Franks and Torous (1994), and Hotchkiss (1995). The numbers shown for the U.S. firms are from the financial statement of the last fiscal year prior to bankruptcy filing. The sample size for the U.S. firms is an average of the sample sizes in the four studies listed above, and data in the table reflect sample-size weighted averages of the results from these studies. The debt-to-assets ratio is defined as book value of total liabilities divided by the market value of equity (book value of equity for the Swedish companies and for the firms studied by Gilson et al., 1990) plus the face value of debt. Current ratio is the ratio of current assets to short term debt. Percentage of firms with negative earnings before interest and taxes (EBIT) is also shown.

\begin{tabular}{|c|c|c|c|c|c|}
\hline & \multicolumn{3}{|c|}{ Swedish firms } & \multicolumn{2}{|c|}{ Publicly traded U.S. firms } \\
\hline & Mean & Median & $\begin{array}{l}\text { Standard } \\
\text { deviation }\end{array}$ & Mean & Median \\
\hline Sample size & 263 & & & 90 & \\
\hline $\begin{array}{l}\text { Book value of assets } \\
\text { ( } \$ \text { million) }\end{array}$ & 2.4 & 1.3 & 3.6 & 288 & 46 \\
\hline Number of employees & 43 & 29 & 48 & 3,000 & 2,000 \\
\hline Debt-to-assets ratio & 0.92 & 0.93 & 0.21 & 0.91 & 0.84 \\
\hline $\begin{array}{l}\text { Long-term debt/book-value } \\
\text { of assets }\end{array}$ & 0.34 & 0.35 & 0.24 & 0.58 & 0.45 \\
\hline Current ratio & 1.39 & 1.23 & 0.97 & 1.06 & 0.99 \\
\hline $\begin{array}{l}\text { Fraction firms with } \\
\text { negative EBIT }\end{array}$ & $46 \%$ & - & - & $62 \%$ & - \\
\hline
\end{tabular}

owner-manager, defined as a CEO holding $10 \%$ or more of the firm's equity, while the remaining firms are managed by an external CEO.

Table 2 lists selected pre-bankruptcy characteristics for the sample firms based on their last reported financial statement. On average, these financial statements were created 16.5 months before filing. For comparison purposes, Table 2 also presents the corresponding information for much larger, publicly traded U.S. firms that file for Chapter 11, as reported by Weiss (1990), Gilson et al. (1990), Franks and Torous (1994), and Hotchkiss (1995). In the Swedish sample, the average book value of total assets one year prior to filing is only $\$ 2.5$ million, with median assets totaling $\$ 1.3$ million. The average number of employees for the Swedish firms is 43 , and the median number of employees is 29 . 
The sample firms are highly leveraged with an average pre-filing debtto-assets ratio of $92 \%$. Interestingly, this ratio is almost identical to the $91 \%$ average debt ratio measured across the Chapter 11 samples. Moreover, reflecting the extensive use of short-term bank financing, the Swedish firms have on average only $34 \%$ of long-term debt in their capital structure, as opposed to $58 \%$ for U.S. firms. Capturing liquidity, the current ratio, defined as current assets to short-term debt, is on average 1.39 for the Swedish sample, as compared to 1.06 for Chapter 11 firms. Also, just less than half of sample firms, $46 \%$, report negative earnings before interest and taxes (EBIT) in the year prior to filing. This level, again, is less than the $62 \%$ of firms with negative EBIT in Hotchkiss' (1995) sample of Chapter 11 cases. Overall, the statistics indicate that, prior to filing, the firms filing for auction bankruptcy are in a comparable financial condition as the firms filing for Chapter 11 .

The financial characteristics of the sample firms after filing for bankruptcy are shown in Table 3. The realized auction value for these firms averages $\$ 0.8$ million, with median auction value of $\$ 0.4$ million, and is similar to the book value reported for private U.S. firms in Chapter 11. ${ }^{5}$ The auction value, which is reported in the filing documents, is the sum of the total proceeds from the sale of assets in the auction, accounts receivables, and other claims owned by the firm and collected by the trustee. This value is only one-third of the average pre-filing book value of assets reported in Table 2 above, and the difference reflects a combination of pre-filing asset sales and book values overstating market values for financially distressed firms. In my sample, one-third of the firms report that they sold non-core assets over the two-year period prior to filing. Asset sales in the two years prior to bankruptcy filing are qualitatively different from auction prepacks. First, these sales occur prior to the firm being bankrupt and second, they do not involve core assets which are the object of the prepackaged going concern sale.

Table 3 also provides information on the debt structure of the sample firms and, for comparison, of U.S. firms in Chapter 11. For the average firm in the sample, $39 \%$ of the total liabilities is secured debt, of which $80 \%$ is floating charge debt and the remainder is fixed charge debt. The proportion of secured debt is similar to the $42 \%$ mean fraction of secured debt reported by White (1984) for privately held firms in Chapter 11 . Moreover, on average $88 \%$ of the sample firms' secured debt is held by banks, with a median of $100 \%$. This amount constitutes the bulk of the bank debt, given that only $6 \%$ of claims held by banks are unsecured. Thus, the sample firms' $39 \%$ mean fraction of secured debt, which includes practically all bank debt, is comparable to the $37 \%$ average

\footnotetext{
${ }^{5}$ The evidence on privately held firms in Chapter 11 is from LoPucki (1983), White (1984), and Lawless et al. (1994). For the evidence on publicly traded firms in Chapter 11, see the references in Table 2, as well as LoPucki and Whitford (1993) and Betker (1997).
} 
Table 3

Debt structure and total assets of Swedish and U.S. firms in bankruptcy, 1978-1993

Table shows debt structure and total assets of 263 privately held Swedish firms filing for auction bankruptcy in 1988-1991, and for publicly traded and privately held U.S. firms filing for Chapter 11 in 1978-1993. Data for the Swedish firms are from the bankruptcy file kept with the supervisory authority, or Tillsynsmyndigheten i Konkurs (TSM). The information on publicly traded firms in Chapter 11 is from Weiss (1990), Gilson et al. (1990), LoPucki and Whitford (1993), Franks and Torous (1994), Hotchkiss (1995), and Betker (1997). The evidence on private firms in Chapter 11 is from LoPucki (1983), White (1984) and Lawless, Ferris, Jayaraman, and Makhija (1994). The sample sizes shown for U.S. firms are averages of the sample sizes in the studies listed above of publicly traded and privately held firms, respectively, and data in the table reflect sample-size weighted averages of the results from these studies. Auction value is the sum of total proceeds from the sale of the firm's assets in the bankruptcy auction, and the value of accounts receivables and other claims owned by the firm and collected by the trustee. For the Swedish firms, bank debt constitutes on average $88 \%$ of the secured debt, median $100 \%$, and banks hold on average $36 \%$ of the total liabilities.

\begin{tabular}{|c|c|c|c|c|c|c|c|}
\hline & \multicolumn{3}{|c|}{ Swedish firms } & \multicolumn{2}{|c|}{$\begin{array}{l}\text { Publicly traded } \\
\text { U.S. firms }\end{array}$} & \multicolumn{2}{|c|}{$\begin{array}{l}\text { Privately held } \\
\text { U.S. firms }\end{array}$} \\
\hline & Mean & Median & $\begin{array}{l}\text { Standard } \\
\text { deviation }\end{array}$ & Mean & Median & Mean & Median \\
\hline Sample size & 263 & & & 79 & & 46 & \\
\hline $\begin{array}{l}\text { Book value of assets } \\
\text { (\$ million) }\end{array}$ & - & - & - & - & - & 1.2 & 0.3 \\
\hline Auction value ( $\$$ million) & 0.8 & 0.4 & 1.2 & - & - & - & - \\
\hline Secured debt/total liabilities & 0.39 & 0.38 & 0.25 & 0.12 & 0.00 & 0.42 & - \\
\hline Bank debt/total liabilities & - & - & - & 0.25 & 0.20 & - & - \\
\hline Priority claims/total liabilities & 0.29 & 0.24 & 0.21 & - & - & - & - \\
\hline Senior debt/total liabilities & - & - & - & - & - & 0.05 & - \\
\hline Junior debt/total liabilities & 0.33 & 0.28 & 0.21 & - & - & 0.54 & - \\
\hline
\end{tabular}

fraction of the sum of secured debt and bank debt reported for publicly traded U.S. firms. Furthermore, of the Swedish firms' total debt, on average $29 \%$ is priority claims, i.e., audit, tax and wage claims, and $33 \%$ is junior unsecured debt. In comparison, White (1984) reports a higher fraction of junior debt, with a mean of $54 \%$, for small firms in Chapter 11 .

\section{Auction prepacks, in-bankruptcy auctions, and firm survival}

This section examines the firm's choice of a pre-negotiated auction prepack versus filing for an in-bankruptcy auction. Moreover, I present evidence on the degree to which the in-bankruptcy auction leads to a going concern sale versus piecemeal liquidation. This analysis sheds light on the extent to which the auction bankruptcy system promotes survival of the filing firms. 


\subsection{Auction prepacks}

In the total sample of 195 going concern sales, 53 sales $(27 \%)$ were arranged just prior to filing for bankruptcy. These cases are labeled prepackaged going concern sales, and referred to as simply auction prepacks. In an auction prepack, a buyer has been found and the rights to the distressed firm's core assets have been transferred to the buyer in return for cash. However, since the amount of cash is less than the sum of the firm's liabilities, the selling firm still must file for bankruptcy. Moreover, for the prepack sales agreement to take effect after filing, it must be formally approved by all secured creditors whose collateral is included in the prepack sale, as well as the bankruptcy trustee. In my sample, there is no evidence of prepacks being overturned. In the case of prepacks, however, the trustee need not open an auction since the assets of the bankrupt firm are now primarily made up of cash. Thus, the trustee can proceed with the distribution of the cash to creditors on an absolute priority basis.

There are several incentives for firms to arrange a prepack. Shareholder claims are eradicated in both auction prepacks and in bankruptcy auctions. This feature makes auction prepacks different from prepackaged Chapter 11 filings, where shareholders retain some equity in the reorganized firm. Nevertheless, certain shareholders, such as those with valuable private information about the firm, or with substantial private benefits of control, may see an advantage in repurchasing the bankrupt company. It is possible that the terms of the repurchase are more favorable to the buyer in a prepack agreement than in the open bankruptcy auction. If this benefit occurs systematically, one would expect the frequency of owner repurchases to be highest in the sample of prepacks. However, I find no support for this proposition in my database. No significant difference exists in the proportion of owner repurchases between the samples of prepacks and going concern bankruptcy sales.

The distressed firm's managers and debtholders may also have a preference for the prepack option. For example, if prepacks have lower direct bankruptcy costs, they benefit debtholders. In fact, as discussed below, there is significant evidence that auction prepacks have lower costs. Furthermore, managers concerned with their prospects for being rehired by the new owners have an incentive to choose the bankruptcy venue with the lowest cost, thus building a reputation for value-maximizing behavior. While not a topic of this paper, Thorburn (2000) shows that CEOs undertaking auction prepacks on average suffer smaller compensation losses when their firms file for bankruptcy.

Firms that select an auction prepack share several characteristics. Table 5 shows the results of a probit regression for the probability that a sample firm files a prepack $(y=1)$ versus files for an auction in bankruptcy $(y=0)$. The estimation uses 205 observations, of which 35 cases are auction prepacks. The regression eliminates the remaining 18 auction prepack cases due to missing 
information on one or more of the explanatory variables. The probit model is described by the following equation:

$$
\begin{aligned}
\text { Prob }(\text { Prepack })= & \alpha_{0}+\alpha_{1} \text { Secured }+\alpha_{2} \text { Float }+\alpha_{3} \text { Distress }+\alpha_{4} \text { Unique } \\
& +\alpha_{5} \text { Ownermgr }+\alpha_{6} \text { Profmarg }+\alpha_{7} \text { Size } \\
& +\alpha_{8} \text { Industry }+\varepsilon .
\end{aligned}
$$

The explanatory variables are defined in Table 4 . Firms with a high proportion of intangibles are more difficult to value, and thus have higher expected auction costs. The variable Secured, which measures the proportion of secured debt in the firm's capital structure, is used as a proxy for the fraction of tangible assets. The expected auction costs are thus higher the lower the value of Secured, and the higher the auction costs the greater the incentive to set up a prepack agreement. Also, the value of intangible assets tends to become diminished if the firm is liquidated piecemeal, which can be avoided through a prepackaged filing. Both arguments predict that the proportion of tangible assets will enter the regression with a negative coefficient, such that $\alpha_{1}<0$. Furthermore, the execution of an auction prepack requires approval by the creditors holding claims secured by core assets. The probability of a prepack is therefore expected to decrease with the number of creditors holding claims secured by floating-charge collateral, labeled Float in Eq. (1), producing $\alpha_{2}<0$.

Industry distress reduces liquidity among competitors and increases the chance that asset will be unloaded in fire sales, thus increasing the incentive creditors have to restructure the company out of court. The variable Distress, defined as the fraction of financially distressed firms in the industry, is therefore predicted to produce a positive coefficient, $\alpha_{3}>0$. A related argument is that firm assets that can be classified as unique within the industry are of a relatively low value to industry outsiders, and will sell at a substantial discount in a piecemeal liquidation. The variable Unique measures the fraction of assets that are classified as industry unique, defined as machinery, equipment, inventory, intangible assets, and work in progress. This variable is expected to have a positive impact on the likelihood that an auction prepack is selected, such that $\alpha_{4}>0$. The value of the unique assets is estimated by the trustee to be on average one-third of total firm value. Non-unique assets include liquid assets, accounts receivables, other financial claims, vehicles, and real estate.

The model also includes a binary variable, Ownermgr, indicating that the firm is run by an owner-manager, holding at least $10 \%$ of the equity in the firm. Owner-managers have both the incentives and the control rights to execute auction prepacks, suggesting that the variable Ownermgr should enter the regression with a positive sign, $\alpha_{5}>0$. The probit model further contains a measure for the firm's pre-filing operating profitability relative to its industry competitors, Profmarg, predicted to increase the probability of a prepackaged going concern sale, such that $\alpha_{6}>0$. Moreover, relatively large firms with 
Table 4

Definition of variables in the regression models

Variable Variable definition

label

Panel A: Firm characteristics

Size Log of book value of total assets in the firm's last financial statement prior to filing.

Large Binary variable indicating that the firm belongs to the one-third of sample firms ( 88 firms) with the largest pre-filing book-value of total assets, ranging from $\$ 2.1$ million to $\$ 4.2$ million.

Medium Binary variable indicating that the firm belongs to the one-third of sample firms ( 88 firms) in the middle range of pre-filing book-value of total assets, ranging from $\$ 0.9$ million to $\$ 2.1$ million.

Profmarg Pre-filing operating profitability, defined as earnings before interest, taxes, amortization and depreciation, EBITDA, divided by total sales, minus the contemporaneous median operating profitability of all Swedish firms with more than 20 employees that shares the same 4-digit SIC code as the sample firm.

Unique Fraction of firm's assets that are unique to the industry, defined as machinery, equipment, inventory, intangible assets and work in progress, as estimated by the trustee upon bankruptcy filing.

Secured Fraction of secured debt to total debt in the firm's capital structure at bankruptcy filing.

Float Number of debt holders secured with floating-charge collateral.

Ownermgr Binary variable indicating that the CEO owns at least $10 \%$ of the firm's equity, vs. less than $10 \%$ of the equity.

Distress Fraction of Swedish firms with over 20 employees sharing the same 4-digit SIC code as the sample firm that either report an interest coverage ratio of less than one in the year of bankruptcy filing, or file for bankruptcy during the next calendar year.

Panel B: Auction characteristics

Creditor Binary variable indicating that a creditor, vs. the firm, files the bankruptcy petition.

Filing91 Binary variable indicating that the firm files for bankruptcy in 1991, vs. in 1988-1990.

Prepack Binary variable indicating that a going concern sale of the firm's core assets is negotiated by the firm prior to bankruptcy filing, vs. a sale is arranged in bankruptcy by the trustee.

Piecemeal Binary variable indicating that the firm's assets are sold piecemeal in the bankruptcy auction, vs. are sold as a going concern.

Bank Binary variable indicating that the filing firm's bank, vs. a new bank, finances the buyer in the auction of the bankrupt firm's assets.

Repurchase Binary variable indicating that the pre-filing owner buys back, vs. a new owner buys, the assets of the firm. Pre-filing owner is defined as an equity holder or a group company of the filing firm, or, if the ownership of the acquirer is unknown, cases where the acquiring firm's board includes all member of the filing firm's board.

Length Number of months that the firm's legal corporate existence is kept on file with the court as an open bankruptcy case. The firm typically continues to exist as a legal entity in bankruptcy for several years after the assets have been sold. 
multiple divisions may have synergies that are lost in a piecemeal liquidation, hence increasing expected auction costs. The variable Size, measured as the log of pre-filing book value of assets, is therefore predicted to produce a positive coefficient, $\alpha_{7}>0$. Finally, the probit estimation adds a number of industry indicators, described by the vector Industry.

As shown in Table 5, the probability of an auction prepack decreases with the amount of secured debt in the firm's capital structure, as expected. Firms with a higher proportion of intangibles, and thus high expected bankruptcy costs, are more likely to choose the prepack option. This result is consistent with Gilson et al. (1990), who find that firms restructuring their debt in a private workout tend to have relatively more intangible assets than firms filing for Chapter 11 . Moreover, the coefficient for firm size is positive, again suggesting that prepackaged bankruptcy is more predominant among firms facing relatively high expected auction costs. In contrast, Betker (1997) reports that firms in traditional Chapter 11 proceedings on average have larger pre-filing assets than firms in Chapter 11 prepacks. As predicted, the variable indicating that the firm is run by an owner-manager produces a positive coefficient, perhaps reflecting the reputational concerns of managers in the selection of auction prepacks. Similarly, prepackaged bankruptcy filings in the U.S. are often characterized by substantial managerial equity ownership. Approximately $40 \%$ of Chapter 11 prepacks involve failed LBO firms in which management typically has significant shareholdings (see, e.g., Jensen, 1989; Betker, 1995).

The coefficients for Float, Unique and Distress, shown in Table 5, are all insignificant, suggesting that the prepack decision is not affected by the number of secured debtholders, asset uniqueness, and industry distress. Also, the relative profitability of the firm has no statistically discernible impact for the probability of an auction prepack. Overall, the regression model is significant with a pseudo- $R^{2}$ of $10.2 \%$ and a likelihood ratio test statistic with a $p$-value of 0.08 . While not shown here, a separate estimation using a subsample of going concern sales produces similar results.

\subsection{Firm survival}

A central issue concerns whether managers facing auction bankruptcy and possible job losses will delay filing. ${ }^{6}$ A delay means that going concern value is destroyed while the restructuring of the firm is postponed, causing the firm to be of relatively low value when entering bankruptcy. In this paper, more than $90 \%$ of the bankruptcy filings are made by the distressed firm. Since the creditor can also file, at first sight this may seem to contradict the hypothesis of delayed filing. However, managers generally have an informational advantage

\footnotetext{
${ }^{6}$ See, e.g., Franks et al. (1996) and White (1996).
} 
Table 5

Comparison of bankruptcy outcomes, Swedish firms, 1988-1991

Parameter estimates in probit regressions for the probability of auction prepack vs. in-bankruptcy auction, and of in-bankruptcy going concern sale vs. piecemeal liquidation. Sample of 205 Swedish firms filing for auction bankruptcy in 1988-1991. In the regressions, the dependent variable is a binary variable, $y$, indicating type of bankruptcy outcome. The first equation compares auction prepacks to in-bankruptcy auctions, with $y$ set to 1 for prepacks and 0 for auctions in bankruptcy. The second equation compares going concern sales in bankruptcy $(y=1)$ to piecemeal liquidations $(y=0)$. An auction prepack is a going concern sale of the distressed firm's core assets that is negotiated by the firm prior to bankruptcy filing. Industry indicators were included for manufacturing, construction, wholesale and retail, hotels and restaurants, and transportation. See Table 4 for variable definitions.

Auction prepack vs. in-bankruptcy auctions
In-bankruptcy going concern sale vs. piecemeal liquidation

$\begin{array}{ccc}\begin{array}{c}\text { Expected sign } \\ \text { of coefficient }\end{array} & \text { Coefficient } p \text {-value } \begin{array}{c}\text { Expected sign Coefficient } p \text {-value } \\ \text { of coefficient }\end{array}\end{array}$

\section{Constant}

Explanatory variables:

$\begin{array}{lcrrrrr}\text { Secured } & <0 & -1.25 & 0.023 & <0 & -0.91 & 0.058 \\ \text { Float } & <0 & -0.13 & 0.522 & - & - & - \\ \text { Creditor } & - & - & - & <0 & -0.69 & 0.058 \\ \text { Distress } & >0 & -0.76 & 0.305 & <0 & -0.72 & 0.333 \\ \text { Unique } & >0 & 0.24 & 0.459 & >0 & 0.01 & 0.986 \\ \text { Ownermgr } & >0 & 0.48 & 0.099 & >0 & -0.29 & 0.278 \\ \text { Profmarg } & >0 & 0.16 & 0.849 & >0 & 0.38 & 0.600 \\ \text { Size } & >0 & 0.38 & 0.008 & >0 & 0.11 & 0.367\end{array}$

Industry indicators with $p$-values less than 0.10 :

None

Sample size:

$$
\begin{aligned}
& y=1 \\
& y=0
\end{aligned}
$$

Pseudo $R^{2}$

Likelihood ratio

test

$-0.07$

0.005

$>0$

0.367
117

49

0.059

$11.79 \quad 0.463$

concerning the financial status of the firm, and may effectively delay filing by withholding such information from creditors. In the U.S., managers have potentially fewer incentives to delay a Chapter 11 filing since they retain substantial control rights throughout the bankruptcy proceeding. Thus, the delayed filing hypothesis predicts that firms filing for auction bankruptcy are less likely to survive as going concerns than firms filing for Chapter 11. 
In the total sample of auction bankruptcies, $74 \%$ of firms survive as going concerns. Excluding auction prepacks, which are all going concern sales, and focusing on the 205 firms sold by the trustee in a public auction, 63 firms (31\%) are liquidated piecemeal and 142 firms $(69 \%)$ are sold as going concerns. The fifth column of Table 5 reports the estimated coefficients in a model for the probability that the firm survives as a going concern as opposed to being liquidated piecemeal in the auction. The estimation uses a subsample of 166 firms sold by the trustee in bankruptcy, of which 49 firms were liquidated piecemeal. The probability of a going concern sale is defined as follows:

$$
\begin{aligned}
\text { Prob }(\text { Survival })= & \alpha_{0}+\alpha_{1} \text { Secured }+\alpha_{2} \text { Creditor }+\alpha_{3} \text { Distress }+\alpha_{4} \text { Unique } \\
& +\alpha_{5} \text { Ownermgr }+\alpha_{6} \text { Profmarg }+\alpha_{7} \text { Size } \\
& +\alpha_{8} \text { Industry }+\varepsilon .
\end{aligned}
$$

In formulating the model expressed in Eq. (2), I expect a going concern sale to be driven by the same factors as an auction prepack. Thus, the model in Eq. (2) contains the same variables as the prepack model in Eq. (1), with the exception of Float, which is omitted from Eq. (2). Moreover, Eq. (2) includes a binary variable, Creditor, indicating whether a creditor, as opposed to the firm, files the bankruptcy petition. If firms that are forced into bankruptcy by a creditor are of lower quality, this setting should reduce the probability of survival, such that $\alpha_{2}<0$. Furthermore, since a piecemeal liquidation would dissipate the value of intangible assets, the probability of a going concern sale is expected to decrease with Secured, or $\alpha_{1}<0$. The likelihood of firm survival is also predicted to be lower in down-sizing or distressed industries, captured by Distress, thus $\alpha_{3}<0$. To the extent the firm's equityholders can influence the trustee's sales effort, the variable Ownermgr is expected to produce $\alpha_{5}>0$, reflecting a greater expected loss of managerial private benefits when the firm is liquidated piecemeal. The model also contains the variables Unique, Profmarg, and Size, which are all expected to increase the likelihood of a going concern sale.

As predicted, the coefficient for Secured is negative, suggesting that firms with a large fraction of intangible assets tend to be auctioned as going concerns. This result is consistent with the earlier finding that auction prepacks are more common for firms with a significant part of their value in intangibles, reflecting higher expected bankruptcy costs. Moreover, the coefficient for Creditor, $\alpha_{2}$, is negative and significant. Thus, firms for which a creditor files the bankruptcy petition seem to have a lower chance of survival, as expected. While the probability of an auction prepack is increasing in the indicator for owner-manager, this variable has no significant impact on the outcome of the bankruptcy auction, possibly indicating that the trustee acts independently of equityholders and managers during the auction. As before, the coefficients for the proportion assets that are industry unique and the level of distress in the industry are insignificant, suggesting that neither asset uniqueness nor industry 
distress affect the choice of going concern sale versus piecemeal liquidation. Finally, the variables capturing industry-adjusted operating profitability and size produce insignificant coefficients, as do the industry indicators. The overall significance of this regression is lower than for the above prepack regression, with a pseudo- $R^{2}$ of $5.9 \%$.

Interestingly, the three-quarter survival rate in Swedish bankruptcy is close to survival rates reported for Chapter 11 filings by privately held firms. White (1984) finds that in a sample of 64 small corporations filing for Chapter 11, 47\% of firms adopt reorganization plans, $23 \%$ are sold as going concerns, and the remaining $30 \%$ are subsequently liquidated under Chapter 7 . Thus, in White's sample, $70 \%$ of the firms continue operating with their assets in their current use. This survival rate is also similar to the finding of Flynn (1989), who reports that, in a sample of 2,395 small Chapter 11 cases with confirmed reorganization plans from 1979 to $1989,25 \%$ had plans to liquidate the firm, which implies a conditional survival rate of $75 \%$. Jensen-Conklin (1992) also study confirmed plans by small firms in Chapter 11, and finds that $25 \%$ were liquidation plans. LoPucki (1983) reports that $27 \%$ of his sample of 48 firms obtain confirmation of a reorganization plan and are still operating three years later. Since this post-to Chapter 11 rate reflects firm-specific economic conditions over the three-year post-bankruptcy period, it understates actual survival rates. Also, LoPucki does not include going concern sales in Chapter 11, which leads to a further understatement of actual survival rates. As to Chapter 11 filings by publicly traded firms, Weiss (1990) reports that in a sample of 35 cases, $86 \%$ successfully reorganize, while LoPucki and Whitford (1993) report a 74\% survival rate for their 43 cases.

In sum, the survival rate in auction bankruptcy is largely indistinguishable from the fraction of firms surviving Chapter 11 filings. One interpretation of this result is that U.S. firms filing for Chapter 11 tend to be in a similar economic condition as the Swedish firms studied here, an explanation that is also consistent with the discussion in Section 2.3, above. If one assumes that only the lowest-quality firms are liquidated piecemeal, this finding also fails to support the hypothesis that managers delay filing under an auction bankruptcy code relative to what is observed under a reorganization code. In contrast, as shown by Thorburn (2000), managers may have incentives to file early to increase the chance of retaining control of the firm after bankruptcy.

\section{Bankruptcy costs}

Total bankruptcy costs are the sum of direct costs, such as lawyer fees, consulting fees, administrative costs, for example, and indirect costs, which include the opportunity cost of management's time and potentially adverse reputational effects in product and capital markets. In this section, I report 
estimates of direct costs as well as the length of time the firm spends in auction bankruptcy. $^{7}$

\subsection{Direct bankruptcy costs}

As shown in Panel A of Table 6, direct costs in bankruptcy auctions, excluding prepacks, average $6.4 \%$ of pre-filing assets. The median level of direct costs in bankruptcy auctions is $4.5 \%$. Note that costs based on pre-filing book value of assets are biased downwards. However, market values of assets prior to filing are generally not available. Moreover, as presented in Panel B of Table 6, auction prepacks are relatively inexpensive. The average direct costs for auction prepacks are $2.5 \%$, with median costs measuring $1.5 \%$. As expected, scaling costs with market value of assets in bankruptcy, using the realized auction proceeds, produces a much higher cost estimate for bankruptcy auctions of on average $19.1 \%$, with median $13.2 \%$. This estimate may contain a potential upward bias if the auction produces an asset fire sales. To make the Swedish results comparable to U.S. studies, I focus in the following primarily on costs measured as a fraction of pre-filing book value of assets.

Table 7 contains ordinary least squares (OLS) estimates of the parameters in two cross-sectional regressions explaining direct bankruptcy costs in percent of pre-filing assets. I choose this scaling rather than realized auction proceeds since the latter is likely to vary with several of the explanatory variables. The regression model is defined as

$$
\begin{aligned}
\text { Costs }= & \alpha_{0}+\alpha_{1} \text { Large }+\alpha_{2} \text { Medium }+\alpha_{3} \text { Piecemeal }+\alpha_{4} \text { Prepack } \\
& +\alpha_{5} \text { Secured }+\alpha_{6} \text { Unique }+\alpha_{7} \text { Distress }+\alpha_{8} \text { Length } \\
& +\alpha_{9} \text { Industry }+\varepsilon .
\end{aligned}
$$

As before, the explanatory variables are defined in Table 4. The model contains two binary variables for firm size, one covering the one-third largest firms in the sample (Large), and the second the one-third intermediate-sized firms (Medium). In the presence of fixed bankruptcy costs, these two variables should have negative signs, thus I expect $\alpha_{1}<0$ and $\alpha_{2}<0$. The regressions further include a binary variable indicating piecemeal liquidation (Piecemeal), and, for the extended sample, an indicator for auction prepack (Prepack). Both of these outcomes are likely to incur lower direct costs than going concern sales in bankruptcy, hence Piecemeal and Prepack are predicted to enter with negative coefficients, or $\alpha_{3}<0$ and $\alpha_{4}<0$.

\footnotetext{
${ }^{7}$ The magnitude of bankruptcy costs is an important determinant of the firm's capital structure. See e.g. Miller (1977), Warner (1977), Haugen and Senbeth $(1978,1988)$ and Harris and Raviv (1991).
} 
Table 6

Direct bankruptcy costs and time in bankruptcy for Swedish and U.S. firms, 1978-1993

Direct bankruptcy costs and time in bankruptcy for 263 private Swedish firms filing for auction bankruptcy in 1988-1991, and for public and private U.S. firms filing for Chapter 11 during 1978-1993. The information on publicly traded firms in Chapter 11 is from Weiss (1990), Gilson et al. (1990), LoPucki and Whitford (1993), Franks and Torous (1994), Hotchkiss (1995), and Betker (1997), and, on Chapter 11 prepacks, from Betker (1995) and Tashjian et al. (1996). The evidence on privately held firms in Chapter 11 is from LoPucki (1983), White (1984), Flynn (1989), and Lawless et al. (1994). The sample sizes shown for the U.S. firms are averages of the sample sizes in the studies listed above of public and private firms, respectively, and data in the table reflect sample-size weighted averages of the results from these studies. Data for the Swedish firms are from the database of UC and the bankruptcy file kept with TSM. For Swedish firms, the time in bankruptcy is measured as the time from filing to sale of the core assets as a going concern. In Sweden, prepack is a going concern sale that is negotiated prior to bankruptcy filing. For U.S. firms, prepack is a bankruptcy filing in which a reorganization plan is negotiated out-of-court.

\begin{tabular}{|c|c|c|c|c|c|c|c|}
\hline & \multicolumn{3}{|c|}{ Swedish firms } & \multicolumn{2}{|c|}{$\begin{array}{l}\text { Publicly traded } \\
\text { U.S. firms }\end{array}$} & \multicolumn{2}{|c|}{$\begin{array}{l}\text { Privately held } \\
\text { U.S. firms }\end{array}$} \\
\hline & Mean & Median & $\begin{array}{l}\text { Standard } \\
\text { deviation }\end{array}$ & Mean & Median & Mean & Median \\
\hline \multicolumn{8}{|c|}{ Panel A: Auctions and reorganizations in bankruptcy } \\
\hline Sample size & 210 & & & 79 & & 46 & \\
\hline $\begin{array}{l}\text { Direct costs/book-value of } \\
\text { pre-filing assets }\end{array}$ & 0.064 & 0.045 & 0.057 & 0.036 & 0.031 & - & - \\
\hline $\begin{array}{l}\text { Direct costs/market value of } \\
\text { assets in bankruptcy }\end{array}$ & 0.191 & 0.132 & 0.189 & - & - & - & - \\
\hline $\begin{array}{l}\text { Direct costs/book-value of } \\
\text { assets in bankruptcy }\end{array}$ & - & - & - & - & - & 0.145 & - \\
\hline Time in bankruptcy (months) & 2.4 & 1.5 & 3.4 & 23 & 19 & 25 & 22 \\
\hline \multicolumn{8}{|l|}{ Panel B: Prepacks } \\
\hline Sample size & 53 & & & 49 & & & \\
\hline $\begin{array}{l}\text { Direct costs/book-value of } \\
\text { pre-filing assets }\end{array}$ & 0.025 & 0.015 & 0.027 & 0.024 & 0.020 & - & - \\
\hline Time in bankruptcy (months) & -2.2 & -0.2 & 4.1 & 2.9 & 1.9 & - & - \\
\hline
\end{tabular}

To capture the effects of market illiquidity on the trustee's level of involvement in the auction sale, the regression includes the variables Secured, Unique and Distress. The higher the fraction of tangible assets, or the higher the value of Secured, the greater its asset liquidity and the lower are expected bankruptcy costs, thus $\alpha_{5}<0$. Moreover, the higher the levels of Unique and Distress, the lower is the expected demand for the assets in the auction, which in turn is expected to lead to higher bankruptcy costs. Both Unique and Distress are 
therefore predicted to enter with positive coefficients, $\alpha_{6}>0$ and $\alpha_{7}>0$. The model also contains a variable, Length, measuring the number of months that the firm's corporate shell is kept on file with the court as an open bankruptcy case. The longer the case is administered in bankruptcy, the more time the trustee tends to spend on the case, thus increasing the overall costs, such that $\alpha_{8}>0$. The time the case is kept on file with the court should not be confused with the time the firm operates in bankruptcy before being auctioned off. Importantly, the Pearson correlation between the time the case is kept on file and the time between filing and going concern sale is a low 0.056 (2-tailed $p$-value of 0.481). I found no data available on the length of the piecemeal auctions. Finally, the probit regression includes a vector of industry dummy variables, Industry.

I also examined an alternative model specification which includes the dummy variable Repurchase, indicating whether or not the old owner repurchases the firm in the auction. While not reported in Table 7, this variable produces an insignificant coefficient. This result is inconsistent with the conjecture that the trustee sells the assets back to the old owner to reduce the trustee's own sales effort.

The second column of Table 7 reports the coefficient estimates from a regression using a subsample of 171 in-bankruptcy auctions, excluding auction prepacks. The regression is significant with an adjusted $R^{2}$ of $25.5 \%$. As indicated by the negative coefficients for the dummy variables capturing size of firm, $\alpha_{1}$ and $\alpha_{2}$, direct bankruptcy costs have significant fixed components. The constant term produced in the model is $6.7 \%$ for the one-third smallest firms in the sample, and decreases by $3.7 \%$ for intermediate-sized firms and $6.1 \%$ for the one-third largest firms. ${ }^{8}$ Consistently, the unconditional direct costs for the one-third largest firms in my sample, excluding prepacks, are on average $3.7 \%$ of pre-filing assets, with median costs measuring $2.5 \%$ of the pre-filing assets. Measured in percent of market value of assets in bankruptcy, the direct costs for the one-third largest firms are on average $14.4 \%$, with a median of $9.7 \%$.

The indicator of a piecemeal sale also produces a negative and significant coefficient, $\alpha_{3}$, suggesting that piecemeal liquidations have lower direct costs than going concern sales, as expected. Interestingly, the regressions in Table 7 imply that bankruptcy costs are increasing in the degree of industry distress, possibly because the bankruptcy trustee must increase sales efforts to find a high-valuation bidder in distressed industries. Moreover, the coefficient for Length, $\alpha_{8}$, is positive and significant, suggesting that the direct costs increase with the time that the case is administered in bankruptcy. This result may raise

\footnotetext{
${ }^{8}$ Direct bankruptcy costs in dollar terms are found to be concave also in the U.S., see, e.g., Warner (1977), Ang et al. (1982) and Betker (1997).
} 
Table 7

Comparison of direct bankruptcy costs, Swedish firms, 1988-1991

OLS coefficient estimates in regressions of direct bankruptcy costs for 213 Swedish firms filing for auction bankruptcy in 1988-1991. Direct costs are the administrative, advisory and legal fees incurred in bankruptcy, in percent of the book value of total assets, as reported in the last financial statement prior to filing. The first regression uses a sample of in-bankruptcy going concern sales and piecemeal liquidations, while the second regression also comprises auction prepacks, which are going concern sales that are negotiated prior to bankruptcy filing. Industry indicators were included for manufacturing, construction, wholesale and retail, hotels and restaurants, and transportation. See Table 4 for variable definitions.

\begin{tabular}{|c|c|c|c|c|c|c|}
\hline \multirow[t]{2}{*}{ Sample criteria: } & \multicolumn{3}{|c|}{ Sample of in-bankruptcy auctions } & \multicolumn{3}{|c|}{ Sample of all filings } \\
\hline & $\begin{array}{l}\text { Expected sign } \\
\text { of coefficient }\end{array}$ & Coefficient & $p$-value & $\begin{array}{l}\text { Expected sign } \\
\text { of coefficient }\end{array}$ & Coefficient & $p$-value \\
\hline Constant & $>0$ & 0.067 & 0.001 & $>0$ & 0.077 & 0.000 \\
\hline \multicolumn{7}{|c|}{ Explanatory variables: } \\
\hline Large & $<0$ & -0.061 & 0.000 & $<0$ & -0.055 & 0.000 \\
\hline Medium & $<0$ & -0.037 & 0.000 & $<0$ & -0.034 & 0.000 \\
\hline Piecemeal & $<0$ & -0.019 & 0.021 & $<0$ & -0.017 & 0.025 \\
\hline Prepack & - & - & - & $<0$ & -0.035 & 0.000 \\
\hline Secured & $<0$ & -0.003 & 0.880 & $<0$ & -0.006 & 0.689 \\
\hline Unique & $>0$ & 0.003 & 0.542 & $>0$ & 0.005 & 0.356 \\
\hline Distress & $>0$ & 0.059 & 0.026 & $>0$ & 0.042 & 0.054 \\
\hline Length & $>0$ & 0.001 & 0.029 & $>0$ & 0.001 & 0.092 \\
\hline \multicolumn{7}{|c|}{ Industry indicators with $p$-values less than 0.10 : } \\
\hline None & - & - & - & - & - & - \\
\hline Sample size & & 171 & & & 213 & \\
\hline$R^{2}$ adjusted & & 0.255 & & & 0.277 & \\
\hline$F$-value & & 5.85 & 0.000 & & 7.24 & 0.000 \\
\hline
\end{tabular}

the issue of whether the cost estimates presented in this paper are biased, since the sample selection procedure eliminates 145 open bankruptcy cases (see Section 2.2). However, within the sample, the unconditional Pearson correlation between the percentage direct costs and time on file is a low 0.073 , producing a 2-tailed $p$-value of 0.274 , providing no support for the existence of such bias in the cost estimates. Furthermore, there is no evidence that the measures for asset type and uniqueness affect direct costs.

Column 5 of Table 7 reports the coefficient estimates based on a sample of 213 firms that also includes 42 auction prepacks. The regression is again significant, and the coefficient estimates are generally consistent with the above results for the subsample of auctions in bankruptcy. The direct costs decrease with firm size and increase with industry distress and the length of the bankruptcy case, with 
no detectable impact of the proportion tangible assets and the degree to which assets are unique to the industry. As expected given the results in Table 6, the coefficient for Prepack, $\alpha_{4}$, is negative and significant. The one-third largest Swedish firms undertaking auction prepacks have unconditional average direct costs of $1.9 \%$ of pre-bankruptcy assets, with median costs of $1.3 \%$.

For comparison purposes, Table 6 also contains extant evidence on costs for much larger, publicly traded firms reorganizing in Chapter 11 . The direct costs for Chapter 11 cases, in percent of book value of pre-filing assets, is estimated at $3.6 \%$, with median direct costs measuring $3.1 \%$. These calculations represent a sample-size weighted average of the cost estimates in Weiss (1990) and Betker (1997). ${ }^{9}$ This average cost estimate corresponds closely to the $3.7 \%$ average costs reported for the one-third largest cases in my auction bankruptcy sample. Moreover, for a sample of 22 privately held small firms in Chapter 11, Lawless et al. (1994) report average direct costs, measured as a fraction of book value of assets in bankruptcy, of $14.5 \%$. In light of the fixed cost components, the statistics indicate that the auction procedure may provide a relatively low-cost mechanism for restructuring firms in bankruptcy. Hansen and Thomas (1998) argue that a conservative estimate of total direct costs for auctioning off large firms in bankruptcy is $2 \%$ of assets.

As in Sweden, prepacks in the U.S. incur lower direct costs than traditional bankruptcy cases. Panel B of Table 6 shows direct costs for prepackaged Chapter 11 filings by publicly traded firms, averaged across the samples in Betker (1995) and Tashjian et al. (1996). The direct costs for Chapter 11 prepacks, measured as a fraction of pre-filing assets, are on average $2.4 \%$, with median costs of $2.0 \%$. This measure is somewhat higher than the direct costs reported for the one-third largest firms executing auction prepacks, which have a mean of $1.9 \%$. Note, however, that the U.S. estimates include costs incurred prior to bankruptcy, while the Swedish estimate does not include pre-filing costs. Overall, prepackaged filings are relatively low-cost options under either bankruptcy system.

\subsection{Time in bankruptcy}

Table 7 and the above comparison with the costs of Chapter 11 proceedings leave out one important fundamental, namely the total time firms operate under bankruptcy protection. Indirect costs, in terms of the opportunity cost of managerial time and negative reputational effects in product and capital markets, increase with the time the firm spends in bankruptcy. For firms sold as going concern in an in-bankruptcy auction, excluding prepacks, the average

\footnotetext{
${ }^{9}$ The results of Warner (1977), Ang et al. (1982), and Altman (1984) are not reported here, since they study firms filing for bankruptcy prior to the 1978 enactment of Chapter 11.
} 
time from filing to the date the assets are sold is 2.4 months, with a median of 1.5 months. Panel A of Table 6 displays these results. Moreover, only one of the 142 firms surviving the bankruptcy auction as going concerns was operating for more than one year in bankruptcy before a buyer was found. Not surprisingly, auction prepack procedures are much shorter than the typical auction bankruptcy case (Panel B of Table 6). Auction prepacks are executed a median of four days before filing for bankruptcy, and incur no further delay due to filing. Because of two outliers which represent prepacks executed very early, the average prepack is executed 2.2 months prior to filing.

The time spent in auction bankruptcy is significantly lower than the average length of a Chapter 11 proceeding. For the 2,395 small firm cases in Flynn (1989), the average time in bankruptcy is reported to be 25 months, with a median of 22 months. Jensen-Conklin (1992) reports 22 months for her sample of 45 small-firm Chapter 11 cases, while, in the sample of 20 small firms studied by LoPucki (1983), the court confirms the reorganization plan on average 10 months after filing. The average time in Chapter 11 appears to be similar for large publicly traded and small privately held firms (see, e.g., Gilson et al., 1990; Weiss, 1990; Franks and Torous, 1994; Betker, 1997; Hotchkiss, 1995). Prepackaged Chapter 11 filings are also less time-consuming than the traditional Chapter 11 proceeding. Betker (1995) and Tashjian et al. (1996) find that the average Chapter 11 prepack for publicly traded firms lasts three months, with a median of two months, from filing until the plan is confirmed by court. Moreover, it takes on average 17 months for a Chapter 11 prepack to be set up prior to filing. Thus, there are strong indications that large firm Chapter 11 prepacks require more time than the typical small firm auction bankruptcy case in Sweden.

\section{Debt recovery rates}

A creditor's expected payoff in bankruptcy affects his or her incentives to renegotiate debt outside of formal bankruptcy proceedings. Moreover, debt recovery rates provide important information on the economic value of firms filing for bankruptcy as well as indirect and direct costs imposed by the bankruptcy proceeding itself. This section examines creditors' recovery rates in Swedish auction bankruptcy cases.

Panel A of Table 8 presents recovery rates, measured as the proportion of the debt's face value repaid in bankruptcy, excluding prepacks. Importantly, recovery rates in my sample are based entirely on market values since the cash settlement in the auction permits a cash distribution to creditors. The overall recovery rate for Swedish firms, averaged across both secured and unsecured debt, is $35 \%$, with median of $34 \%$. Focusing on the different classes of debt, secured creditors receive on average $69 \%$, or median $83 \%$, of the face value of 
Table 8

Debt recovery rates for Swedish and U.S. firms filing for bankruptcy, 1985-1993

Debt recovery rates for 263 private Swedish firms filing for auction bankruptcy in 1988-1991, and for publicly traded U.S. firms filing for Chapter 11 in 1985-1993. Debt recovery rate is defined as the payment to a class of debtholders, measured as a fraction of the face value of claims held by that debt class. The information on firms in traditional Chapter 11 proceedings is from Franks and Torous (1994). The evidence on Chapter 11 prepacks is from Tashiian et al. (1996). Data on the Swedish firms are from the database of UC and the bankruptcy file kept with TSM. The subsample of Swedish going concern sales shown in Panel C comprises 142 firms that were auctioned as going concerns in bankruptcy. The subsample of U.S. firms shown in Panel C consists of 12 firms that completed their Chapter 11 restructuring in 1985-1990, and for which market values were available for all claims distributed in the reorganization. For Swedish firms, auction prepack is a going concern sale that is negotiated prior to bankruptcy filing. For U.S. firms, prepack is a Chapter 11 filing in which a reorganization plan is negotiated out-of-court.

\begin{tabular}{|c|c|c|c|c|c|c|}
\hline & \multicolumn{3}{|c|}{ Swedish firms } & \multicolumn{3}{|c|}{ Publicly traded U.S. firms } \\
\hline & \multicolumn{3}{|c|}{ Market values } & \multicolumn{2}{|c|}{ Face values } & \multirow{2}{*}{$\begin{array}{c}\begin{array}{c}\text { Market } \\
\text { values }\end{array} \\
\text { Median }\end{array}$} \\
\hline & Mean & Median & $\begin{array}{l}\text { Standard } \\
\text { deviation }\end{array}$ & Mean & Median & \\
\hline \multicolumn{7}{|c|}{ Panel A: In-bankruptcy auctions } \\
\hline Sample size & 210 & & & & & \\
\hline All debt classes & 0.35 & 0.34 & 0.21 & - & - & - \\
\hline Secured debt & 0.69 & 0.83 & 0.33 & - & - & - \\
\hline Priority claims & 0.27 & 0.19 & 0.28 & - & - & - \\
\hline Junior debt & 0.02 & 0.00 & 0.11 & - & - & - \\
\hline \multicolumn{7}{|c|}{ Panel B: Piecemeal liquidations } \\
\hline Sample size & 63 & & & & & \\
\hline All debt classes & 0.27 & 0.25 & 0.24 & - & - & - \\
\hline Secured debt & 0.50 & 0.45 & 0.36 & - & - & - \\
\hline Priority claims & 0.21 & 0.14 & 0.26 & - & - & - \\
\hline Junior debt & 0.02 & 0.00 & 0.12 & - & - & - \\
\hline \multicolumn{7}{|c|}{ Panel C: Going concern sales and successful reorganizations } \\
\hline Sample size & 142 & & & & 38 & 12 \\
\hline All debt classes & 0.39 & 0.38 & 0.19 & - & 0.51 & 0.41 \\
\hline Secured debt & 0.77 & 0.87 & 0.28 & - & 0.80 & - \\
\hline Priority claims & 0.30 & 0.20 & 0.29 & - & - & - \\
\hline Senior debt & - & - & - & - & 0.47 & - \\
\hline Junior debt & 0.02 & 0.00 & 0.11 & - & 0.29 & - \\
\hline \multicolumn{7}{|c|}{ Panel D: Prepacks } \\
\hline Sample size & 53 & & & 49 & & \\
\hline All debt classes & 0.32 & 0.31 & 0.22 & 0.73 & - & - \\
\hline Secured debt & 0.74 & 0.89 & 0.32 & 0.99 & - & - \\
\hline Priority claims & 0.26 & 0.19 & 0.28 & - & - & - \\
\hline Senior debt & - & - & - & 1.00 & - & - \\
\hline Junior debt & 0.01 & 0.00 & 0.07 & 0.64 & - & - \\
\hline
\end{tabular}


their debt, and priority claims receive on average $27 \%$, with a median of $19 \%$. Unsecured creditors, however, on average recovers only $2 \%$, with median value of zero, reflecting the strict adherence to APR in auction bankruptcy.

The distributions to creditors are significantly lower in auctions where the firm is closed down and its assets sold piecemeal. As shown in Panel B, the overall recovery rate for the subsample of 63 firms that were liquidated piecemeal is on average $27 \%$, with a median of $25 \%$. Also, secured creditors recover less money in these auction cases, with an average payback of $50 \%$, with a median of $45 \%$.

All claimholders seem to recover a higher proportion when the auction preserves the firm as a going concern. Panel $\mathrm{C}$ of Table 8 reports recovery rates for the subsample of 142 firms auctioned in bankruptcy as going concerns. The average overall recovery rate is $39 \%$, with median $38 \%$, such that secured debtholders receive an average of $77 \%$, median $87 \%$, and junior unsecured creditors $2 \%$, median $0 \%$. For a subsample of 58 firms auctioned as going concerns prior to the economic downturn in 1991, the overall recovery rate averages $40 \%$, with median $40 \%$.

Moreover, Panel D of Table 8 shows recovery rates for the 53 auction prepacks. The overall recovery rate in Swedish prepacks is slightly lower than that reported above for auctions in bankruptcy, with a mean of $32 \%$ and median of $31 \%$. Secured creditors receive on average $74 \%$, median $89 \%$, while junior creditors again receive basically nothing.

Table 9 reports OLS estimates of coefficients in two regressions with total recovery rates and recovery rates for secured debt as dependent variables. The sample includes 168 observations of the first type, and 162 observations of the second type. The regression model has the following specification:

$$
\begin{aligned}
\text { Recovery }= & \alpha_{0}+\alpha_{1} \text { Profmarg }+\alpha_{2} \text { Secured }+\alpha_{3} \text { Creditor }+\alpha_{4} \text { Piecemeal } \\
& +\alpha_{5} \text { Prepack }+\alpha_{6} \text { Size }+\alpha_{7} \text { Unique }+\alpha_{8} \text { Distress } \\
& +\alpha_{9} \text { Filing } 91+\alpha_{10} \text { Repurchase }+\alpha_{11} \text { Bank } \\
& +\alpha_{12} \text { Industry }+\varepsilon .
\end{aligned}
$$

Firms with a high pre-filing cash flow performance, captured by Profmarg, are likely to have a higher going concern value, thus I predict $\alpha_{1}>0$. Because the value of intangible assets may get dissipated in the bankruptcy auction, recovery rates are expected to increase in Secured, such that $\alpha_{2}>0$. Moreover, to the extent creditor filing implies lower firm quality, the variable Creditor will produce a negative coefficient, or $\alpha_{3}<0$. Debtholders are further expected to recover less in piecemeal liquidations, Piecemeal, reflecting loss of going concern value, or $\alpha_{4}<0$. Debt recovery is also assumed to decrease with firm size, the fraction industry unique assets and industry distress.

Sweden experienced an economy-wide downturn in 1991, which led to a general decline in asset prices in the later years of the sample period. To account for 
the effects of this recession, the regression includes a binary variable indicating that the firm filed for bankruptcy in 1991, Filing91, which is expected to have a negative impact on recovery rates, thus $\alpha_{9}<0$. The model further contains a binary variable for the case that the pre-filing owner buys back the assets of the firm, Repurchase. In $54 \%$ of the going concern sales, the old owner wins the auction and repurchases the firm. If owners tend to repurchase the firm when they have private information that it is of relatively high quality, Repurchase should enter with a positive coefficient, or $\alpha_{10}>0$. Similarly, the financing of the successful buyer in the auction by the filing firm's bank, represented by Bank, is expected to be associated with higher recovery rates, thus $\alpha_{11}>0$. The model also controls for auction prepacks and industry characteristics, described by the vector Industry.

The regressions reported in Table 9 are significant, with adjusted $R^{2}$ of $12.2 \%$ and $22.1 \%$, respectively, and several of the sign predictions are borne out. Recovery rates are increasing in the proportion of secured debt in the firm's capital structure, possibly reflecting a lower liquidity for intangible assets. As expected, the coefficient for bankruptcy filings in 1991, $\alpha_{9}$, is negative and significant, indicating generally lower auction prices during the period of economic recession. Moreover, consistent with Table 8, the estimated coefficient for piecemeal sales, $\alpha_{4}$, is negative, suggesting that recovery rates tend to be lower in piecemeal liquidations than in going concern sales, which do not enter with a separate dummy in the regression, while $\alpha_{5}$ for auction prepacks is insignificant.

Recovery rates are higher when the old bank refinances the buyer in the auction, yielding $\alpha_{11}>0$. Furthermore, the coefficient for a repurchase of the firm, $\alpha_{10}$, is positive in the second regression, indicating that secured creditors, usually banks, on average recover more when the original owner buys back the firm. This occurrence may simply reflect the on average somewhat lower proportion of secured debt in these cases. Contrary to expectations, there is little evidence that recovery rates depend on pre-filing operating profitability, creditor filing, industry distress, or asset uniqueness. Also, Size produces a statistically insignificant coefficient, $\alpha_{6}$, failing to indicate any systematic variation in recovery rates with firm size.

Before turning to the U.S. evidence, a caveat on measurement issues. In a Chapter 11 reorganization, the claims on the bankrupt firm are settled mainly with new financial securities, as opposed to cash. In the average Chapter 11 reorganization studied by Franks and Torous (1994), 71\% of creditors' total payments are received in the form of new financial securities, and $29 \%$ in cash. Recovery rates reported for Chapter 11 are therefore based largely on the face value of non-traded claims. In light of the significant default rates following Chapter 11 shown by Hotchkiss (1995), the face value of debt significantly overstates its market value. Consistent with this, Eberhart et al. (1990) report a value-weighted ratio of market-to-face value of $80 \%$ for debt claims distributed in Chapter 11 to the creditors of Wickes Companies. 
Table 9

Comparison of debt recovery rates, Swedish firms, 1988-1991

OLS estimates of coefficients in regressions of debt recovery rates. Sample of 168 firms filing for Swedish auction bankruptcy in 1988-1991. In the first regression, the independent variable is the overall debt recovery rate for the firm, and in the second regression the independent variable is the recovery rate for secured debtholders. Debt recovery rate is the payment in bankruptcy to a class of debtholders divided by the face value of claims held by that debt class. Industry indicators were included for manufacturing, construction, wholesale and retail, hotels and restaurants and transportation. See Table 4 for a definition of the variables.

\begin{tabular}{|c|c|c|c|c|c|c|}
\hline & \multicolumn{3}{|c|}{ Overall recovery rate } & \multicolumn{3}{|c|}{ Recovery rate for secured debt } \\
\hline & $\begin{array}{l}\text { Expected sign } \\
\text { of coefficient }\end{array}$ & Coefficient & $p$-value & $\begin{array}{l}\text { Expected sign } \\
\text { of coefficient }\end{array}$ & Coefficient & $p$-value \\
\hline Constant & & 0.498 & 0.087 & & 1.185 & 0.005 \\
\hline \multicolumn{7}{|c|}{ Explanatory variables: } \\
\hline Profmarg & $>0$ & -0.107 & 0.322 & $>0$ & -0.224 & 0.146 \\
\hline Secured & $>0$ & 0.301 & 0.001 & - & - & - \\
\hline Creditor & $<0$ & -0.059 & 0.306 & $<0$ & -0.128 & 0.138 \\
\hline Piecemeal & $<0$ & -0.094 & 0.042 & $<0$ & -0.110 & 0.098 \\
\hline Prepack & $>0$ & -0.026 & 0.569 & $>0$ & -0.034 & 0.609 \\
\hline Size & $<0$ & -0.008 & 0.644 & $<0$ & -0.022 & 0.376 \\
\hline Unique & $<0$ & -0.003 & 0.901 & $<0$ & 0.018 & 0.595 \\
\hline Distress & $<0$ & -0.112 & 0.480 & $<0$ & -0.351 & 0.130 \\
\hline Filing91 & $<0$ & -0.099 & 0.035 & $<0$ & -0.138 & 0.045 \\
\hline Repurchase & $>0$ & 0.016 & 0.706 & $>0$ & 0.114 & 0.060 \\
\hline Bank & $>0$ & 0.070 & 0.087 & $>0$ & 0.195 & 0.001 \\
\hline \multicolumn{7}{|c|}{ Industry indicators with $p$-values less than 0.10 : } \\
\hline None & - & - & - & & - & - \\
\hline Sample size & & 168 & & & 162 & \\
\hline$R^{2}$ adjusted & & 0.122 & & & 0.221 & \\
\hline$F$-value & & 2.46 & 0.001 & & 4.05 & 0.000 \\
\hline
\end{tabular}

Only one existing study reports recovery rates for Chapter 11 cases entirely based on market values. Franks and Torous (1994) provide market-value based estimates of recovery rates for a subsample of 12 publicly traded firms that successfully completed their Chapter 11 reorganization, as shown in Panel C of Table 8 . They find a median overall recovery rate of $41 \%$, which compares to the $39 \%$ recovery rate for Swedish firms auctioned as going concerns. For the full sample of 38 Chapter 11 cases, Franks and Torous (1994) report a median overall recovery rate of $51 \%$, based largely on face values. If the firms in their two samples have similar economic values and default probabilities, the difference in recovery rates provides further indirect evidence that face values 
overstate market values. Moreover, for the latter sample, Franks and Torous report a median recovery of $80 \%$ for secured debtholders and $29 \%$ for junior debt. The substantial payment promised to junior debtholders in Chapter 11 represents a deviation from APR. ${ }^{10}$ In contrast, as pointed out earlier, the cash payment in the auction ensures that claims are settled according to absolute priority, an arguably attractive feature of auction bankruptcy. Jensen (1991) claims that the observed deviations from APR under the U.S. Chapter 11 generate large inefficiencies by increasing firms' cost of capital. Others, however, have argued that ex post deviations from APR are potentially beneficial in terms of reducing underinvestment inefficiencies as well as the time spent in bankruptcy reorganization (see, e.g., Franks and Torous, 1989; Weiss, 1990).

While recovery rates are similar across auction prepacks and in-bankruptcy auctions, debtholders seem to recover substantially more in prepackaged than in traditional Chapter 11 filings. Tashjian et al. (1996) report that creditors of publicly traded firms filing Chapter 11 prepacks recover on average $73 \%$ of the face value of their debt claims. Moreover, the mean recovery rate of secured creditors is a high $99 \%$, and for unsecured creditors it is $64 \%$. While not explored here, this difference between the Swedish and the U.S. evidence possibly reflects the different selection processes behind prepacks under the two bankruptcy systems alluded to in Section 3.1, above.

\section{Conclusions}

There is an international trend away from pure auction bankruptcy systems towards Chapter 11 style reorganization codes. During the last 20 years, several European countries, including the U.K., Germany, France, Finland, Norway, and Sweden, have changed or are proposing changes to, their bankruptcy regulation, much in the direction of the U.S. Chapter 11. This trend takes place despite a largely unresolved empirical debate as to the relative efficiency of bankruptcy auctions. In this study, I examine 263 small firms filing for auction bankruptcy in Sweden over the period 1988-1991, and make systematic comparisons to extant evidence on U.S. Chapter 11 cases. However, while U.S. firms may choose a court-supervised reorganization under Chapter 11, no such provisions effectively exist in Sweden, where the bankruptcy code is an auction procedure. Thus, every Swedish firm filing for bankruptcy is subsequently auctioned off, either as a going concern or piecemeal, under the supervision of an independent, court-appointed trustee.

The analysis yields several interesting results. First, three-quarters of firms survive the bankruptcy auction as going concerns. This survival rate is similar to

\footnotetext{
${ }^{10}$ See, e.g., Franks and Torous (1989), Eberhart et al. (1990) and Weiss (1990).
} 
the survival rates observed for U.S. Chapter 11 filings for small and large firms. Moreover, in Sweden, one-quarter of the going concern sales, comprising $20 \%$ of all filings, are auction prepacks, in which the buyer negotiates the purchase of the firm's assets prior to filing for bankruptcy. The probability of a going concern sale increases with the fraction of intangible assets. Interestingly, auction prepacks are more likely to occur when the firm is run by an ownermanager, perhaps reflecting managerial concerns with post-bankruptcy reputation.

Second, direct bankruptcy costs are found to decrease with firm size, and to be lower in piecemeal liquidations and auction prepacks. The percentage costs, measured as a fraction of pre-filing assets, average $6.4 \%$ for the total sample and $3.7 \%$ for the one-third largest firms. The latter estimate is similar to costs reported for much larger publicly traded U.S. firms in Chapter 11. Direct costs are also increasing in industry distress, possibly reflecting a higher sales effort by the trustee when industry demand is low. Importantly, indirect costs are almost certainly lower under auction bankruptcy, due to the significantly shorter time firms operate in bankruptcy. This period can last from 1 to 2 months in Sweden, and can extend to approximately two years in the U.S.

Third, debtholders recover on average $35 \%$ of their debt in auction bankruptcy. Secured creditors recover approximately $70 \%$ on average, with median amount of $80 \%$, while junior unsecured creditors recover almost nothing. Using market values, and avoiding a potential upward bias in face values, overall debt recovery rates seem to be similar across small firms in auction bankruptcy and publicly traded firms filing for Chapter 11 . For firms surviving as going concerns under both set of circumstances, the average recovery rate is approximately $40 \%$. However, junior creditors receive a relatively smaller piece of the pie in auction bankruptcy, reflecting the strict adherence to absolute priority made possible by the cash settlement in the auction.

Easterbrook (1990) suggests that if auctions are more efficient than court supervised debt reorganizations, one should observe firms being sold under Chapter 11 proceedings. In fact, the 1980s saw the emergence of an active market for claims of firms in Chapter 11. During the last decade, vulture funds specializing on claims of distressed firms have taken significant positions in most of the large Chapter 11 cases. ${ }^{11}$ Moreover, Hotchkiss and Mooradian (1998) find positive abnormal stock returns on acquisition announcements for both target firms in Chapter 11 and bidders, signaling a positive market reaction to the ending of the Chapter 11 proceeding. The emergence of vulture funds as well as other out-of-court solutions such as prepacks and public debt exchanges is further evidence that market transactions, such as auctions, often dominate court supervised reorganizations in the U.S. environment.

${ }^{11}$ See, e.g., Lieb (1993), and Hotchkiss and Mooradian (1997). 
The results in this paper suggest that auction bankruptcy is a speedy, low cost procedure compared to reorganizations under the U.S. Chapter 11. Moreover, firm survival rates, debt recovery rates, and pre-filing financial characteristics are comparable across the two systems. Overall, the evidence indicates that auction bankruptcy in fact provides an efficient mechanism for restructuring small firms.

\section{References}

Aghion, P., Hart, O., Moore, J., 1994. The economics of bankruptcy reform. Journal of Law, Economics and Organization 8, 523-546.

Altman, E., 1984. A further empirical investigation of the bankruptcy cost question. Journal of Finance 39, 1067-1089.

Altman, E., 1993. Corporate Financial Distress and Bankruptcy. Wiley, New York.

Ang, J., Chua, J., McConnell, J., 1982. The administrative costs of corporate bankruptcy: a note. Journal of Finance 37, 219-226.

Baird, D., 1986. The uneasy case for corporate reorganizations. Journal of Legal Studies 15, 127-147.

Bebchuk, L., 1988. A new approach to corporate reorganizations. Harvard Law Review 101, 775-804.

Berkovitch, E., Israel, R., 1995. The bankruptcy decision and debt contract renegotiation. Unpublished working paper, University of Michigan, Ann Arbor, MI.

Betker, B., 1995. An empirical examination of prepackaged bankruptcy. Financial Management 24, 3-18.

Betker, B., 1997. The administrative costs of debt restructurings: some recent evidence. Financial Management 26, 56-68.

Bradley, M., Rosenzweig, M., 1992. The untenable case for Chapter 11. Yale Law Journal 101, 1043-1095.

Easterbrook, F., 1990. Is corporate bankruptcy efficient? Journal of Financial Economics 27, 411-418.

Eberhart, A., Moore, W., Roenfeldt, R., 1990. Security pricing and deviations from the absolute priority rule in bankruptcy proceedings. Journal of Finance 45, 1457-1469.

Eckbo, E., Thorburn, K., 2000a. Toeholds and fire-sales in bankruptcy auctions. Unpublished working paper, Dartmouth College, Hanover, NH.

Eckbo, E., Thorburn, K., 2000b. The resolution of financial distress in a cash auction bankruptcy environment. Unpublished mimeo, Dartmouth College, Hanover, NH.

Flynn, E., 1989. Statistical analyses of Chapter 11. Unpublished study. Administrative Office of the U.S. Courts, Washington, DC.

Franks, J., Nyborg, K., Torous, W., 1996. A comparison of US, UK and German insolvency codes. Financial Management 25, 86-101.

Franks, J., Torous, W., 1989. An empirical investigation of U.S. firms in reorganization. Journal of Finance 44, 747-770.

Franks, J., Torous, W., 1994. A comparison of financial recontracting in distressed exchanges and Chapter 11 reorganizations. Journal of Financial Economics 35, 349-370.

Gilson, S., John, K., Lang, L., 1990. Troubled debt restructurings: an empirical study of private reorganization of firms in default. Journal of Financial Economics 27, 315-353.

Hansen, R., Thomas, R., 1998. Auctions in bankruptcy: theoretical analysis and practical guidance. International Review of Law and Economics 18, 159-185.

Harris, M., Raviv, A., 1991. The theory of capital structure. Journal of Finance 46, 297-355. 
Haugen, R., Senbeth, L., 1978. The insignificance of bankruptcy costs to the theory of optimal capital structure. Journal of Finance 33, 383-393.

Haugen, R., Senbeth, L., 1988. Bankruptcy and agency costs: their significance to the theory of optimal capital structure. Journal of Financial and Quantitative Analysis 23, 27-38.

Hotchkiss, E., 1995. Post-bankruptcy performance and management turnover. Journal of Finance $50,3-21$.

Hotchkiss, E., Mooradian, R., 1997. Vulture investors and the market for control of distressed firms. Journal of Financial Economics 43, 401-432.

Hotchkiss, E., Mooradian, R., 1998. Acquisitions as a means of restructuring firms in Chapter 11. Journal of Financial Intermediation 7, 240-262.

Jensen, M., 1989. Active investors, LBOs, and the privatization of bankruptcy. Journal of Applied Corporate Finance 2, 35-44.

Jensen, M., 1991. Corporate control and the politics of finance. Journal of Applied Corporate Finance 4, 13-33.

Jensen-Conklin, S., 1992. Do confirmed Chapter 11 plans consummate? the results of a study and analysis of the law. Commercial Law Journal 97, 297-331.

Lawless, R., Ferris, S., Jayaraman, N., Makhija, A., 1994. A glimpse at professional fees and other direct costs in small firm bankruptcies. University of Illinois Law Review 4, 847-888.

Lieb, R., 1993. Vultures beware: risks of purchasing claims against a Chapter 11 debtor. The Business Lawyer 48, 915-941.

LoPucki, L., 1983. The debtor in full control - systems failure under Chapter 11 of the bankruptcy code? American Bankruptcy Law Journal 57, 99-126 and 247-273.

LoPucki, L., Whitford, W., 1993. Patterns in the bankruptcy reorganization of large, publicly held companies. Cornell Law Review 78, 597-618.

Miller, M., 1977. Debt and taxes. Journal of Finance 32, 261-275.

Pulvino, T., 1998. Do asset fire-sales exist? an empirical investigation of commercial aircraft transactions. Journal of Finance 53, 939-978.

Ravid, A., Sundgren, S., 1998. The comparative efficiency of small-firm bankruptcies: a study of the U.S. and Finnish bankruptcy codes. Financial Management 27, 28-40.

Roe, M., 1983. Bankruptcy and debt: a new model for corporate reorganization. Columbia Law Review 83, 527-602.

Shleifer, A., Vishny, R., 1992. Liquidation values and debt capacity: a market equilibrium approach. Journal of Finance 47, 1343-1366.

Strömberg, P., 2000. Conflicts of interest and market illiquidity in bankruptcy auctions: theory and tests. Journal of Finance, forthcoming.

Strömberg, P., Thorburn, K., 1996. An empirical investigation of Swedish corporations in liquidation bankruptcy. EFI Research Report, Stockholm School of Economics, Sweden.

Thorburn, K., 2000. Auction bankruptcy and the CEO. Unpublished working paper, Dartmouth College, Hanover, NH.

Tashjian, E., Lease, R., McConnell, J., 1996. An empirical analysis of prepackaged bankruptcies. Journal of Financial Economics 40, 135-162.

Warner, J., 1977. Bankruptcy costs: some evidence. Journal of Finance 32, 337-347.

Weiss, L., 1990. Bankruptcy resolution: direct costs and violation of priority of claims. Journal of Financial Economics 27, 285-314.

White, M., 1984. Bankruptcy liquidation and reorganization. In: Logue, D., Seward, J. (Eds.), Handbook of Modern Finance. Warren, Gorham \& Lamont, Boston, pp. E7-1-E7-44.

White, M., 1996. The costs of corporate bankruptcy: a U.S. - European comparison. In: Bhandari, J., Weiss, L. (Eds.), Corporate Bankruptcy: Economic and Legal Perspectives. Cambridge University Press, England, pp. 467-500. 